\title{
Changing Spectrum of Migrants entering Greek Refugee Camp 2019 in Comparison to 2015/2016. (Psychological and social challenge) (Letter to The Editor)
}

\section{Trilisinskaya (Ioanna Trilisinskaya) ', , T. Simonek (Thomas Simonek) 1,2, M. Jackulikova (Maria Jackulikova), 1, K. Prochazkova (Katarina Prochazkova)1,2, M. Jancovic (Mario Jancovic),1,2, M. Bielova (Maria Bielova)1,2, J. Bydzovsky (Jan Bydzovsky) 1,2, R. Vlcek (Robert Vlcek) 1,2, M. Katunska (Monika Katunska) 1,2, H. Konosova (Helena Konosova)², E. Grey (Eva Grey) 1,2, J. Otrubova (Jana Otrubova) 1,2, L. Radkova (Libusa Radkova)',2, M. Gulasova (Monika Gulasova) 1,2. T. Hrindova (Tatiana Hrindova),', L. Libova (Lubica Libova), 1, A. Murgova (Anna Murgova), ,2, M. Sramkova (Maria Sramkova) 1,2, I. Hupkova (Inge Hupkova) 1,2, A. Topolska (Alexandra Topolska),2, B. Hofbauerova (Blanka Hofbauerova) 1,2, M. Popovicova (Maria Popovicova) 1,2, M. Bakos (Marian Bakos)',2, M. Hardy (Maria Hardy)1,2}

Refugee and Migrant Health Programe, UNHCR Lesbos, Greece.

2 St. Lesley College, Nove Zamky, St. Dominic Institute Michalovce, St. Sarah Institute, Roznava, Slovakia, Martin Luther Institute, Backi Petrovec, Serbia.

\section{E-mail address:}

tomas.simonek@gmail.com

\section{Reprint address:}

Ioanna Trilisinskaya

Refugee and Migrant Health Programe

UNHCR Lesbos

Greece

Source: Clinical Social Work and Health Intervention Volume: $10 \quad$ Issue: 4

Pages: $\quad$ Cited references: 5

\section{Reviewers:}

Andrea Shahum

University of North Carolina at Chapel Hill School of Medicine, USA

George Benca

House of Family, Phnom Penh, Cambodia

Keywords:

Spectrum of Migrants. 


\section{Publisher:}

International Society of Applied Preventive Medicine i-gap

CSWHI 2019; 10(4): 60 - 62; DOI: 10.22359/cswhi_10_4_11 @ 2019 Clinical Social Work and Health Intervention

\section{Abstract:}

Spectrum of migrants to EU is changing. The aim of this letter is to assess the necessary change of psychological and social attitude to the new wave of migrants. Table 1 shows changes of the spectrum of the nationality of migrants to Lesbos UNHCR. Situation has substantially changed within last 3 years, when in 2015 and 2016 Syrian and Iraqui refugees were prevalent .In 2019 Afghaistan and Sub-Saharan Africa are in more than $50 \%$ of all residents of the Camp. Therefore psychological, social and medical approach must be modifyed from previous operations.

\section{To the editors:}

Spectrum of migrants to EU is changing. Previous studys from Greece, Slovenia, Bosna and other Balcan countries in 20152018 showed majority of Sirian and Iraqui nationals (1-5). The aim of this letter is to assess the necessary change of psychological and social attitude to the new wave of migrants. Table 1 shows changes of the spectrum of the nationality of migrants to Lesbos UNHCR Refugee camp Moria. The change of the spectrum significantly (more African and Afghani migrants) is a signal for a change of screening and operational policy.

Table 1: Changes of nationality of Migrants in 2019 comparing to 2016.

\begin{tabular}{|l|c|c|}
\hline Country & 2016 & 2019 \\
\hline Syria & 1 & 3 \\
\hline Iraq & 2 & 6 \\
\hline Afghanistan & 4 & 1 \\
\hline Other ME & 3 & 4 \\
\hline SS Africa & 6 & 2 \\
\hline Other & 5 & 5 \\
\hline
\end{tabular}

\section{References:}

1. WORLD HEALTH ORGANISATION (2017) Operations Manual WHO Geneve, 2017, 155 pp.

2. KALAVSKY E, HERDICS G, VALOVA J, SUBRAMANIAN S, BYDZOVSKY J, RIDOSKO J, SIMONEK T, PALUN M, VANSAC P, NADDOUR A, SUVADA J (2018) Emergencies in Migrant and Refugee Health 2015-2018 (Letter) In: Clinical Social Work and Health Intervention, Vol. 9, Issue 3, 2018 pp 56-57.

3. SUBRAMANIAN S, BELOVICOVA M, VANSAC P, PALUN M, RADKOVA L, OTRUBOVA J, VLCEK R, BENCA J, OLAH M, MATULNIKOVA L, SRAMKOVA M, CMOREJ P, KRCMERY V, SHAHUM A (2018) Rehabilitation and Nursing homes with Elderly and Homeless Population, Lessons not only for Physiotherapy but also for Epidemiology?, In: Clinical Social Work and Health Intervention, Vol: 9, Issue: 3, 2018 pp. 64-66

4. BELOVICOVA M, MURGOVA A, VANSAC P, POPOVICOVA M, BALAZOVA I, NEMCIKOVA M, MASTEROVA V, URBANOVA A, FABISKOVA K, BALAZIOVA A (2019) Hepatitis C Screening in 
selected social reintegration facillities in Eastern Slovakia. In: Clinical Social Work and Health Intervention. Vol. 10, Issue 2, 2019, pp. 25-31
5. UNITED NATIONS HIGH COMMISION FOR REFUGEES ANNUAL REPORT (2018) UNHCR, New York, 2019, 206 pp. 